\title{
Pathology of the alimentary tract in Salmonella typhimurium food poisoning
}

\author{
J F BOYD
}

From the Brownlee Laboratory, Ruchill Hospital, Glasgow and University Department of Pathology, Western Infirmary, Glasgow

SUMmaRY The pathology of the alimentary tracts of nine patients dying of Salmonella typhimurium infection is reviewed. Two patients had previous gastric operations, supporting previous reports that such patients are more susceptible to food poisoning. Four had no parietal (oxyntic) cells in the gastric mucosa, suggesting hypo- or anacidity. Only one had acute gastritis. None had acute enteritis, but in half of the patients, subtle histological changes suggested an 'enteropathy'. Acute diffuse colitis with abundant crypt abscesses, without stromal abscesses in the lamina propria, was the most constant finding and reparative features started very early, and occurred in later deaths. Under ideal circumstances this crypt abscess is readily distinguished from that of idiopathic ulcerative colitis, but can be confused with the crypt abscess of acute bacillary (sonne) dysentery. While the florid colonic changes may have settled in the late deaths, active inflammation is commonly present in the appendix mucosa on histology. The pathology of the alimentary tract in $S$ typhimurium infection differs from that of $S$ typhi and $S$ paratyphi infections. There is little evidence of gastroenteritis, although subtle changes occur in the stomach and small intestine. The features are those of acute diffuse colitis with histological appendicitis, distinguishable from idiopathic ulcerative colitis.

Statistics suggest that the incidence of food poisoning in the United Kingdom is increasing. poisoning is commonly referred to as 'gastroenteritis', implying inflammation of the stomach and small intestine. During an outbreak of $S$ typhimurium (phage type 32) infection in the west of Scotland in 1968 , it was surprising to find virtually no gastritis, or enteritis, and that the predominant histological lesion was an acute diffuse colitis. ${ }^{2}$ Further experience has been gained from $S$ typhimurium infection of other phage types and from other salmonella subtypes. ${ }^{3}$ Other publications ${ }^{4-11}$ have confirmed the colitis component of $S$ typhimurium infection, but the findings in the stomach and small intestine remain un-reported. Indeed, the colonic findings have not been adequately described. In this paper the pathology of the alimentary tract in nine patients dying from $S$ typhimurium infection, involving at least four phage types is described. The first necropsy was done before phage typing had been routinely accepted.

Address for correspondence: Dr J F Boyd, Brownlee Laboratory, Ruchill Hospital, Glasgow G20 9NB.

Received for publication 26 October 1984

\section{Methods}

\section{NECROPSIES}

The nine necropsies were carried out as soon after death as possible. Two loops of jejunum and two of sigmoid colon were sent for microbiological examination and virology. Blood samples from the right auricle were also taken for culture and Widal tests.

The necropsy was standard with the gastrointestinal tract being dissected out and opened with the minimum of handling. Hosing with water and sponging was avoided to allow inspection of the luminal contents and the undisturbed mucosal surfaces.

After formalin fixation standard sets of blocks for histological examination were taken from the gastric fundus, jejunum, jejuno-ileal region, ileum, appendix, and from the ascending, transverse and descending colon. These were chosen to include any obvious pathology at these sites. In all 27 blocks of stomach, 43 of small intestine, 27 of appendix and 90 of colon were examined. All tissue was paraffin embedded and stained with haematoxylin and eosin. Standard special stains were carried out when thought necessary. 


\section{Results}

PATIENTS

Clinical data are shown in Table 1. Patient 1 developed diarrhoea and vomiting when less than one month old. No pathogen was isolated from watery stool specimens during the 10 days in another hospital. After recovery the infant remained well for seven days when less severe diarrhoea developed. On the second admission no pathogen was cultured from a number of stool specimens and the illness settled with gain in weight after two weeks. Pyrexia, however, developed two weeks later - that is, 10 days before death. Penicillin was given, but had no effect. Blood culture four days before death (34 days after the second admission) yielded $S$ typhimurium. The stools became loose again on the day before death. These observations, in conjunction with the histology, suggest that the infant's alimentary $S$ typhimurium illness was about one day's duration.

Patients 4-7 were ill at home, then admitted to other hospitals before being transferred to Ruchill Hospital. Patient 6 became ill on transit to Tunisia, and circulatory complications to her left leg arose while there. Medical attention was given in Tunisia, but an emergency disarticulation at the hip joint was undertaken within two days of her return to Glasgow. She was in a very toxic state and she died six days later.

\section{NECROPSY FINDINGS}

\section{Stomach}

Two patients (5 and 7, Table 1) had undergone gastric surgery. Patient 5 had hypertrophic and patient 9 very atrophic gastric mucosa. Acidsecreting cells were not identified in four $(50 \%)$ of the stomachs (Table 2). Only one patient (no. 2) had acute gastritis with abundant crypt abscesses (Fig. $1)$. Very occasional minor crypt abscesses and epithelioid granulomata in the mucosa indistinguishable from Crohn's disease, were present in patient 7 . Thus, gastritis was florid in only one patient who was one of the four patients not showing oxyntic cells.

\section{Small intestine}

The macroscopic abnormalities were minimal with mild swelling and oedema of some of the mucosal ridges. In four patients $(2,3,4$ and 9$)$ the terminal ileum was reddened and suggested a reflux ileitis.

Histological examination showed that in four cases the small bowel was normal (4, 6, 8 and 9). The villi were normal in height and width. Of the other five cases only one (2) had well established acute inflammatory changes while in the remaining four these were mild (Table 3). This took the form

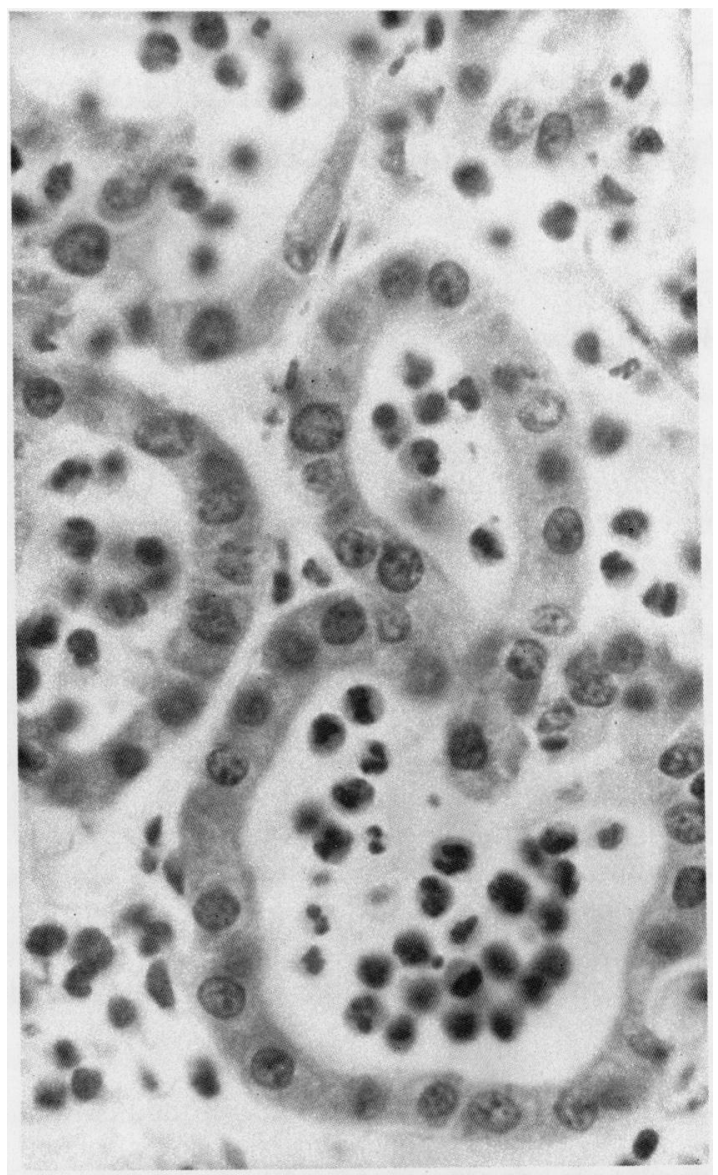

Fig. 1 Patient 2. Stomach. Crypt abscesses lined with nondescript cubical and squamoid epithelium with high nucleus/cytoplasm ratios. $H$ and E. Original $\times 1000$.

of occasional crypts plugged by mucin and macrophages with ingested nuclear debris. Some crypts were lined by nondescript 'embryonal-like' cells with prominent nucleoli and haematoxyphilic cytoplasm (Fig. 2). Occasional capillary thrombi were observed and some perivascular inflammation in the lamina propria. No granulomas or fissures were seen and Peyer's patches were not prominent.

Thus only one patient had a well established enteritis with recognisable crypt abscesses and four had mild 'enteropathic' changes.

\section{Large intestine}

Three colons (nos. 2, 3 and 4) were grossly normal, two were collapsed (1 and 7), two (6 and 8) were moderately dilated. Patient 8 had diverticulosis of the sigmoid and a $15 \mu \mathrm{l}$ abscess in the pouch of 


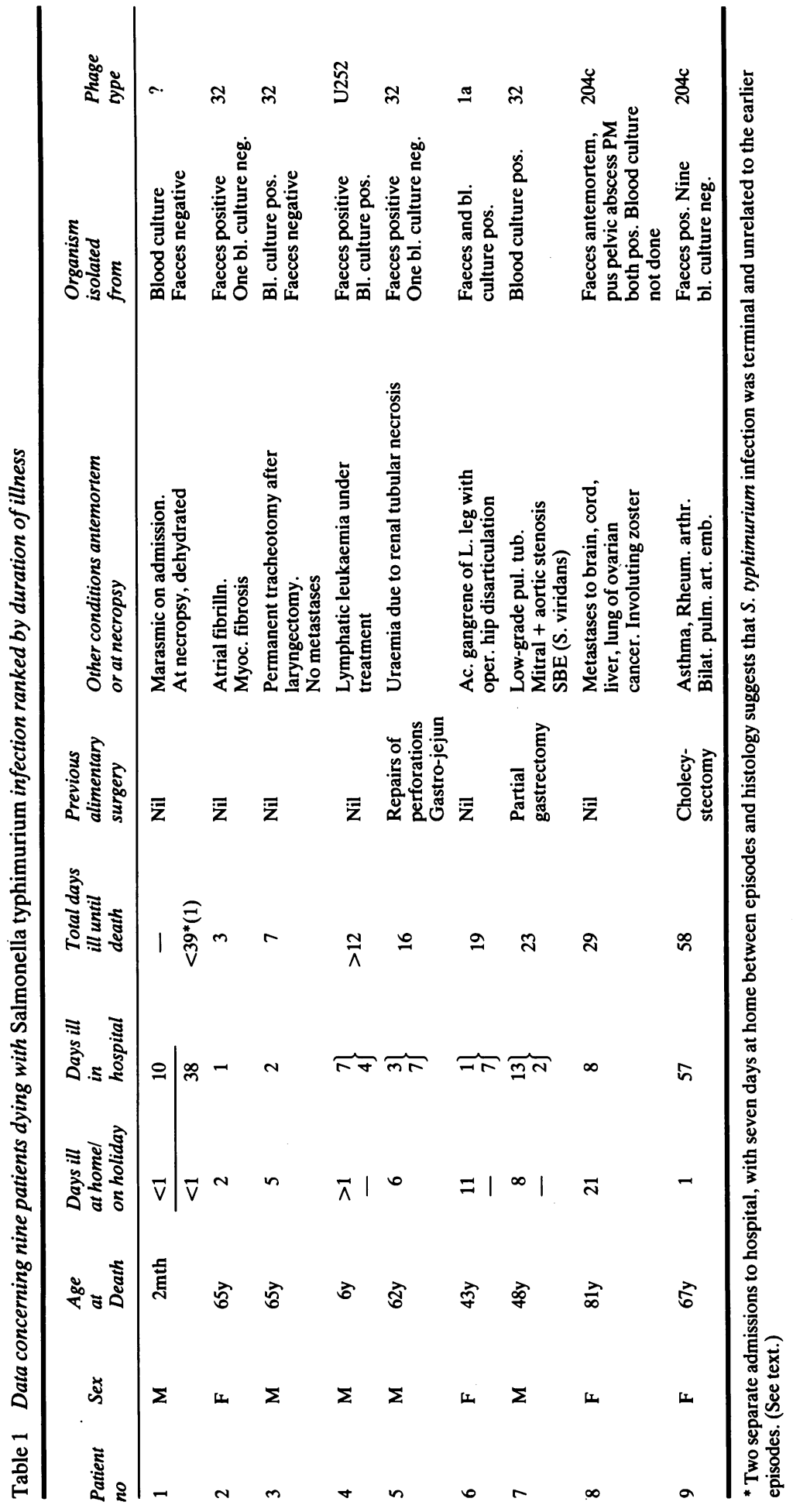


Table 2 Summary of histological findings in the stomach

\begin{tabular}{|c|c|c|c|c|c|c|}
\hline No & $\begin{array}{l}\text { Parietal (oxyntic) } \\
\text { cells }\end{array}$ & $\begin{array}{l}\text { Chronic } \\
\text { gastritis }\end{array}$ & $\begin{array}{l}\text { Intestinal } \\
\text { metaplasia }\end{array}$ & $\begin{array}{l}\text { Acute crypt } \\
\text { abscesses }\end{array}$ & $\begin{array}{l}\text { Acute inflammation } \\
\text { of lamina propria }\end{array}$ & $\begin{array}{l}\text { Granulomata in } \\
\text { lamina propria }\end{array}$ \\
\hline 1 & Specimen not taken & & & & & \\
\hline 2 & - & - & - & ++++ & ++ & - \\
\hline 3 & - & ++ & ++ & \pm & - & - \\
\hline 4 & - & + & ++ & - & - & - \\
\hline 5 & + & + & + & - & - & - \\
\hline 6 & - & - & - & - & - & - \\
\hline 7 & ++ & ++ & - & \pm & - & + \\
\hline 8 & ++++ & ++ & - & - & - & - \\
\hline 9 & ++++ & - & - & - & - & - \\
\hline
\end{tabular}

Douglas with no connection to diverticula, from which $S$ typhimurium was cultured. Two had toxic dilatation, of the whole colon (no 5) or of the caecum and ascending colon only (no 9). Patient 9 also had diverticulitis.

The mucosa was grossly normal in patients $1,5,6$ and 9 (apart from the diverticulitis) despite the histology in patient 1 , and the toxic megacolon in patients 5 and 9 . In patient 8 the mucosa was patchily red. The mucosal ridges were red throughout in patient 2 , while the mucosa was diffusely red beyond the splenic flexure in patients 3 and 4 . The mucosa of patient 7 was cyanotic from the sigmoid flexure. All these features might have been ignored, if the history of a diarrhoeal illness had not been available. There was no melaena, or bloodstaining in any case.

The histological features are summarised in Table 4. Patient 1 showed universal loss of the mucosal surface and the exposed lamina propria displayed shallow diffuse fibrinoid necrosis along the entire bowel wall covered by haematoxyphylic (Gram negative) bacteria (Fig. 3). The columnar cells lining the lower halves of the crypts had prominent eosinophilic nucleoli, hyperchromic nuclei, raised nuclear/cytoplasmic ratios and abundant mitotic activity. Crypt abscesses were absent. The lamina propria showed oedematous granulation tissue with new capillary loops growing into the zone of fibrinoid necrosis. Some capillaries showed fibrin/ platelet thrombi. The deeper lamina propria and the submucosa contained a mixed inflammatory infiltrate.

Varying mucosal surface repair with crypt abscesses occurred in all acute deaths. Patient 2 (three day illness) showed abundant crypt abscesses (Fig. 4) rich in eosinophil leucocytes, neutrophil polymorphs, plasma cells, lymphocytes, mononuclear cells, and desquamated crypt lining cells. A few crypts were ballooned with squamoid lining cells at the sides and necks, but at the bases, cells were stratified upon one another. The lamina propria showed no stromal abscesses. Scattered haemorrhages and very scanty capillary thrombi were

Table 3 Summary of histological findings in the small intestine

\begin{tabular}{|c|c|c|c|c|c|c|c|c|}
\hline No & $\begin{array}{l}\text { Protein-rich } \\
\text { vesicles at } \\
\text { villous tips }\end{array}$ & $\begin{array}{l}\text { Acute focal } \\
\text { enteritis with } \\
\text { crypt abscesses }\end{array}$ & $\begin{array}{l}\text { Plasma cells in } \\
\text { lamina propria } \\
\text { considered to be } \\
\text { excessive }\end{array}$ & $\begin{array}{l}\text { Non- } \\
\text { differentiated } \\
\text { crypt columnar } \\
\text { epithelium with } \\
\text { no brush border, } \\
\text { high nucl/cyto } \\
\text { ratio, prominent } \\
\text { nucleoli }\end{array}$ & $\begin{array}{l}\text { Excessive } \\
\text { exfoliation of } \\
\text { lining cells into } \\
\text { crypt lumen }\end{array}$ & $\begin{array}{l}\text { Inspissated } \\
\text { mucin plugs in } \\
\text { crypt lumina }\end{array}$ & $\begin{array}{l}\text { Capillary } \\
\text { thrombosis in } \\
\text { villous stroma } \\
\text { and/or lamina } \\
\text { propria }\end{array}$ & $\begin{array}{l}\text { Perivenous } \\
\text { cuffing by } \\
\text { lymphocytes } \\
\text { and/or } \\
\text { neutrophil } \\
\text { polymorphs in } \\
\text { submucosa }\end{array}$ \\
\hline 1 & ++ & - & - & - & - & - & - & - \\
\hline 2 & - & ++ & - & + & - & \pm & \pm & \pm \\
\hline 3 & - & \pm & ++ & \pm & \pm & - & - & - \\
\hline 4 & - & - & - & - & - & - & - & - \\
\hline 5 & - & \pm & ++ & \pm & \pm & - & - & - \\
\hline 6 & - & - & - & - & - & - & - & - \\
\hline 7 & - & \pm & ++ & \pm & \pm & - & - & - \\
\hline 8 & - & $\overline{-}$ & - & $\overline{-}$ & $\overline{-}$ & - & - & - \\
\hline
\end{tabular}




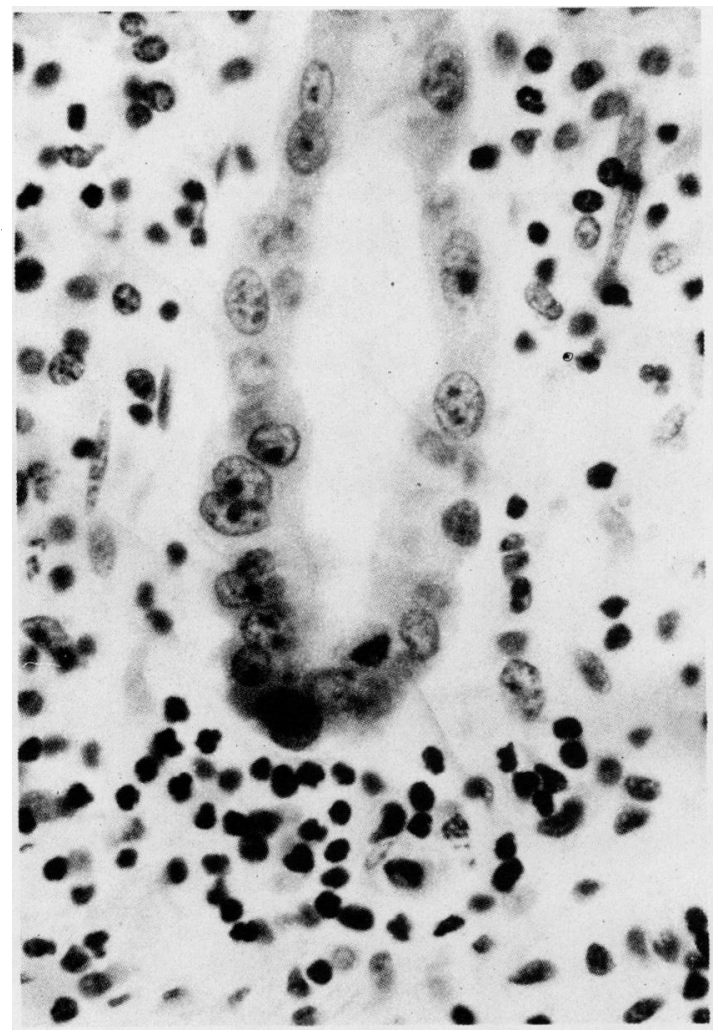

Fig. 2 Patient 3. Small intestine. Crypt of Lieberkühn lined by cubical 'embryonal' epithelium. Lymphocytes (? cleaied) are at the crypt base, in the lamina propria. $H$ and $E$. Original $\times 1000$.

present. The submucosa was very oedematous with mild cellulitis and lymphangitis.

Patient 3 (seven days) had a non-differentiated columnar surface epithelium (Fig. 5). Patient 5 (16 days) had ballooned crypts, some with mucin plugs. others with cell debris and a few showed abscesses. Most crypts were rich in goblet cells. Patient $6(19$ days) had tall crypts with abundant goblet cells, but there were isolated ballooned crypts with cell debris in the lumen, and flattened epithelium round their walls. The superficial lamina propria showed persisting necrosis. Patient 7 ( 23 days) had tall crypts (Fig. 6) rich in goblet cells, a normal quota of goblet cells on the surface and a moderately dense infiltration of lymphocytes superficially in the lamina propria that is. where fibrinoid necrosis is assumed to have been. Patients 8 ( 29 days) and 9 ( 58 days) had no additional features.

All patients had subtle acute diffuse colitis with crypt abscesses in most and evidence of repair. Granulomata and fissures were absent. While histological recovery could occur by two weeks (no 4), evidence of continuing infection could still be seen at four weeks (no 8).

\section{Appendix}

All appendices appeared grossly normal, but were studied histologically in patients 2 to 9 (Table 5).

Appendicitis was most severe in patient 3 with zones of fibrinoid necrosis, scanty crypt abscesses, and excessive mucopus in the lumen. Patient 7 showed an epithelioid granuloma in the lamina propria, similar to the stomach findings. The inflammatory changes were more severe in the appendix than in the colon of the same patient, although in toto there was more inflammation in the colon.

\section{Discussion}

This series suggests that the young and the elderly are most likely to die from food poisoning, but it also shows that patients need not be debilitated. The patients had clinical states similar to those reported by Dickinson and Pickens. ${ }^{13}$

The relative absence of gross features at necropsy

Table 4 Summary of the histological findings in the large intestine

\begin{tabular}{|c|c|c|c|c|c|c|c|c|}
\hline No & $\begin{array}{l}\text { Superficial } \\
\text { fibrinoid } \\
\text { necrosis }\end{array}$ & $\begin{array}{l}\text { Cript } \\
\text { abscesses }\end{array}$ & $\begin{array}{l}\text { Ballooned } \\
\text { cripts }\end{array}$ & $\begin{array}{l}\text { Non- } \\
\text { differentiated } \\
\text { epithelium }\end{array}$ & $\begin{array}{l}\text { Reappearance } \\
\text { of goblet cells }\end{array}$ & $\begin{array}{l}\text { Stromal } \\
\text { inflammation } \\
\text { of lamina } \\
\text { propria }\end{array}$ & $\begin{array}{l}\text { Lymphocytic } \\
\text { infiltration in } \\
\text { superficial } \\
\text { lamina propria } \\
\text { mucosae }\end{array}$ & $\begin{array}{l}\text { Paneth cells per } \\
\text { inch of colon } \\
\text { wall }\end{array}$ \\
\hline 1 & ++++ & - & - & ++ & - & +++ & - & - \\
\hline 2 & - & ++++ & \pm & +++ & - & ++ & - & - \\
\hline 4 & - & - & - & - & ++ & - & - & \pm \\
\hline 5 & - & + & + & \pm & +++ & - & - & - \\
\hline 6 & + & - & \pm & \pm & +++ & - & - & - \\
\hline 7 & - & - & - & - & ++++ & - & ++ & - \\
\hline 8 & - & \pm & \pm & \pm & ++++ & - & + & \pm \\
\hline 9 & - & - & - & - & ++++ & - & - & - \\
\hline
\end{tabular}




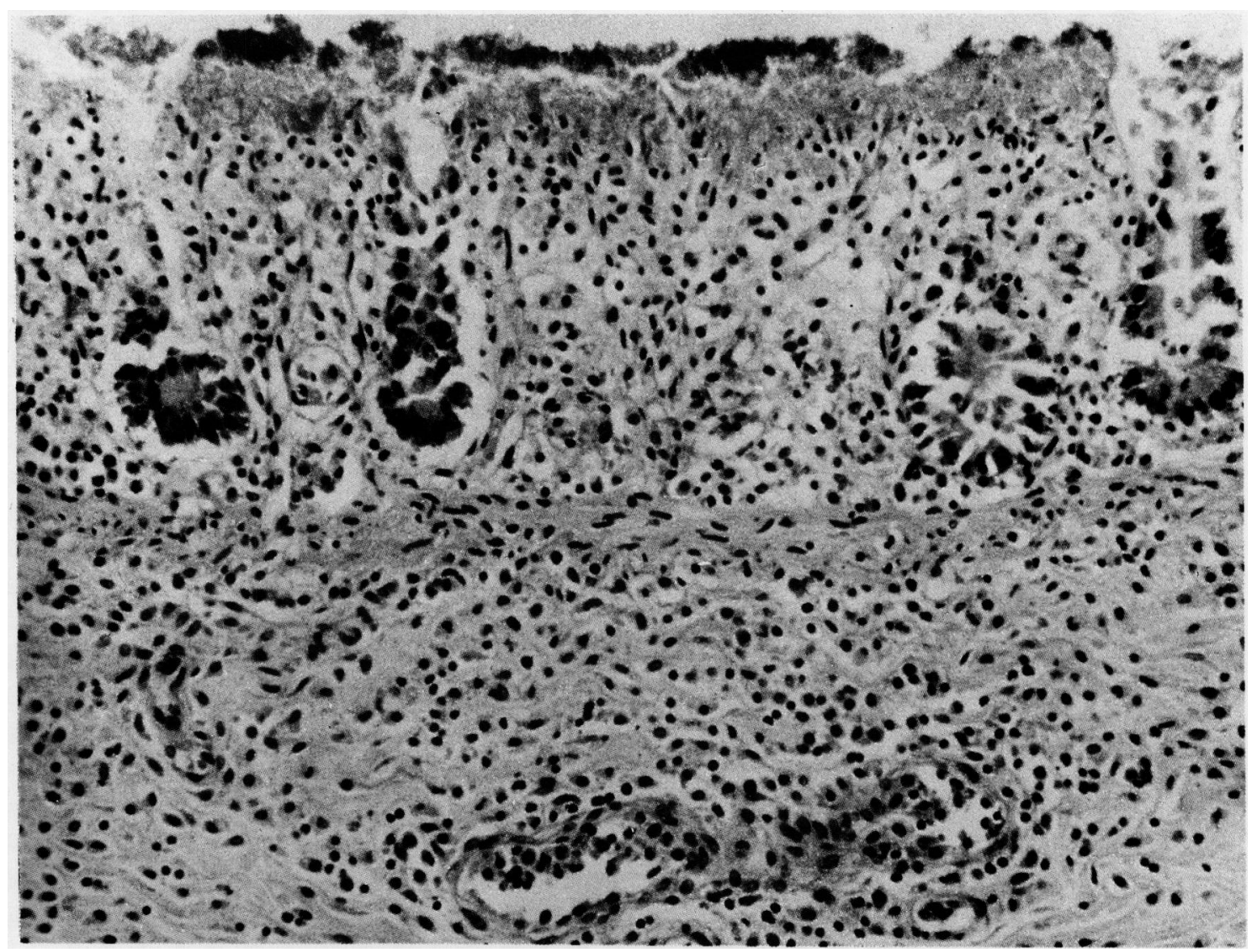

Fig. 3 Patient 1. Large intestine. Representative field. Incomplete haematoxyphilic layer of bacilli (Gram-negative) overlying a shallow fairly even layer of fibrinoid necrosis into which new capillary loops are migrating from the lamina propria. The crypts of Lieberkühn are lined by non-differentiated columnar cells, squamoid at the crypt necks. The submucosa shows widespread cellulitis and the venules show pavementing by neutrophil polymorphs. $H$ and $E$. Original $\times$ 250.

Table 5 Summary of the histological findings in the appendix

\begin{tabular}{|c|c|c|c|c|c|c|c|c|c|}
\hline No & $\begin{array}{l}\text { Superficial } \\
\text { fibrinoid } \\
\text { necrosis }\end{array}$ & $\begin{array}{l}\text { Crypt } \\
\text { abscesses }\end{array}$ & $\begin{array}{l}\text { Ballooned } \\
\text { crypts }\end{array}$ & $\begin{array}{l}\text { Non- } \\
\text { differentiated } \\
\text { epithelium }\end{array}$ & $\begin{array}{l}\text { Epithelioid } \\
\text { cell } \\
\text { granuloma }\end{array}$ & $\begin{array}{l}\text { Pus in the } \\
\text { lumen }\end{array}$ & $\begin{array}{l}\text { Excess mucin } \\
\text { in the lumen }\end{array}$ & $\begin{array}{l}\text { Hyperplastic } \\
\text { mucosa }\end{array}$ & $\begin{array}{l}\text { Paneth cells } \\
\text { per } \\
\text { circumference } \\
\text { of organ }\end{array}$ \\
\hline 1 & Not taken & & & & & & & & \\
\hline 2 & - & \pm & - & - & - & \pm & - & - & 0 \\
\hline 3 & ++ & + & - & - & - & + & ++ & - & 1 \\
\hline 4 & - & - & \pm & ++ & - & - & - & - & 20 \\
\hline 5 & - & \pm & - & - & - & - & - & - & 10 \\
\hline 6 & - & \pm & + & - & - & ++ & - & + & 50 \\
\hline 7 & - & $=$ & - & - & + & - & - & + & 40 \\
\hline 8 & - & - & - & - & - & - & - & - & 5 \\
\hline 9 & - & - & - & - & - & - & - & - & 1 \\
\hline
\end{tabular}




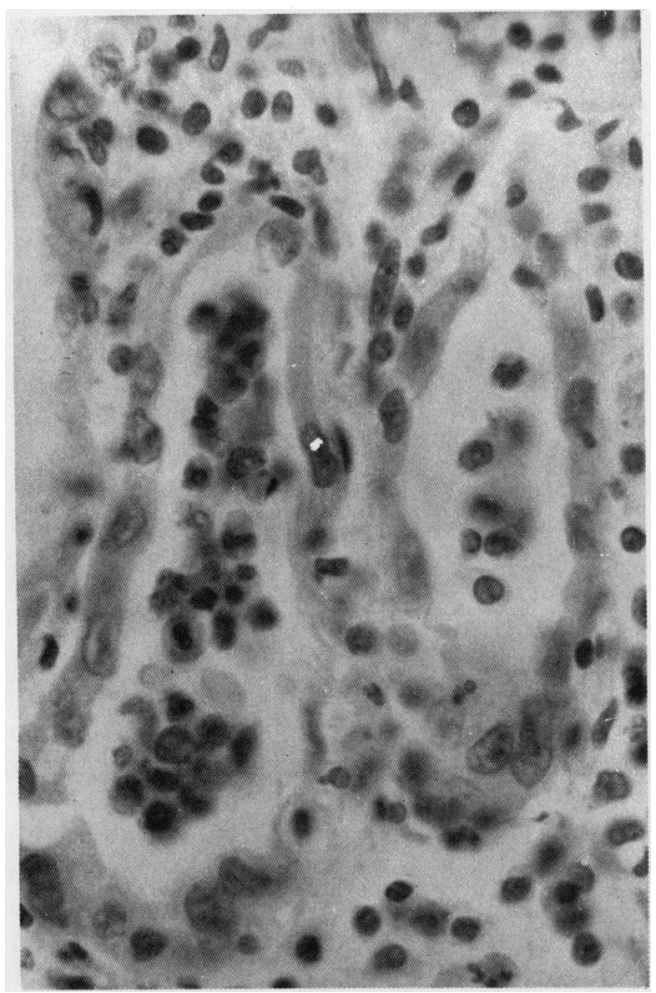

Fig. 4 Patient 2. Colon. Three adjacent crypts of Lieberkühn lined by primitive squamoid epithelium with prominent nucleoli. The more cellular crypt abscess contains neutrophil polymorphs, an eosinophil leucocyte, mononuclear cells and a few lymphocytes. $H$ and $E$. Original $\times 1000$.

can be misleading. Histology of the gastric mucosa showed no parietal cells in half the subjects, reinforcing ideas of Hurst in $1934^{14}$ and others, ${ }^{15-18}$ that patients with hypo- or anacidity, or with stomach operations are more susceptible than normal persons to food poisoning. The relative absence of acute gastritis is important.

The absence of swollen ulcerated Peyer's patches and the paucity of acute inflammation in the small intestine are important but there were changes which were difficult to explain. Generalised enteritis was not recorded in any patient, only one showing focal enteritis, but in about half there was evidence of repair of the crypts and mucosal surfaces by a non-differentiated epithelium. The infection is occasionally choleraic, ${ }^{19} 20$ a cholera toxin like enterotoxin has been reported recently, ${ }^{21} 22$ and three patients (nos 2, 3 and 5) had excessive fluid in the bowel to simulate paralytic ileus at necropsy. This discovery fails to explain the observations reported

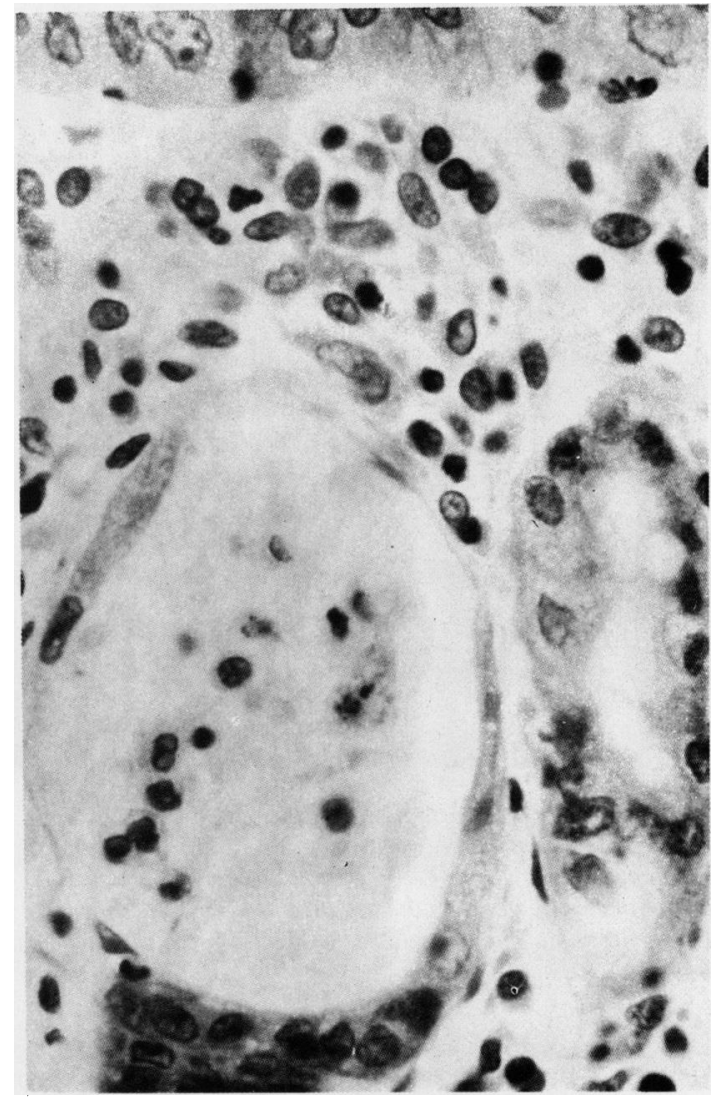

Fig. 5 Patient 3. Colon. Early goblet cell differentiation in the right-hand crypt. Florid repair in the left-hand crypt has caused stratification at the base, with ballooning. The contents are equally neutrophil polymorphs, lymphocytes and cell debris. The surface bears non-differentiated columnar cells, and goblet cells are absent. $H$ and $E$. Original $\times 1000$.

above, because there is no sloughing or ulceration of the small bowel mucosa on biopsy in true cholera. ${ }^{23}$ The small intestines of four patients (nos 4, 6, 8 and 9) showed no histological abnormality, and therefore a cholera like enterotoxin might have been present in these cases. The 'enteropathy' of four patients (nos 2, 3, 5 and 7) may be the consequences of the action of the cytotoxin which has been described in the last two years, ${ }^{24}$ and it is interesting that phage type 32 was responsible for the illness of these four patients (Table 1). This illness has been described previously as 'salmonella gastro-enteritis', but in the present study gastritis and enteritis were minimal. A more satisfactory term therefore may be salmonella food poisoning. ${ }^{13}$ It is noted that 'infantile gastro-enteritis' shows no gastritis or enteritis on 


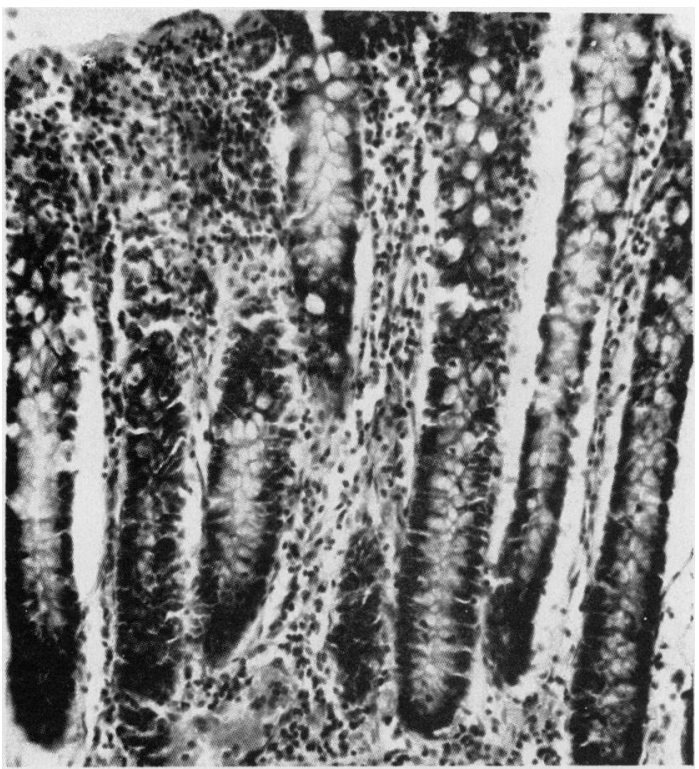

Fig. 6 Patient 7. Colon. The crypts are deeper than normal, and possibly more numerous than normal, with a normal quota of goblet cells. There is a condensation of lymphocytes however in the lamina propria immediately below the surface layer, where the layer of fibrinoid necrosis may have existed. $H$ and $E$. Original $\times 250$.

histology, but, when associated with specific types of Escherichia coli, commonly shows acute ileitis. ${ }^{25-27}$ $S$ typhimurium infection caused 'gastro-enteropathy' in only half of this series, but in contrast, Yersinia infections ${ }^{128-30}$ may cause enteritis and ileitis severe enough to need laparotomy. No such infections have been seen in this department ${ }^{31}$ which serves medical units only. Whether or not salmonella infections may cause chronic ulcerative enteritis ${ }^{32}$ remains uncertain.

$S$ typhimurium causes greatest histological damage in the colon. ${ }^{2-11}$ In this country the illness may be confused with bacillary dysentery, or idiopathic Ilcerative colitis. Patients with idiopathic ulcerative colitis may develop superinfection by $S$ typhimurium. ${ }^{33}$ The gross changes in the colons of the patients of this series were minimal, and toxic megacolon can occur (patients 5 and 9). ${ }^{34}$

A pathologist should be able to distinguish idiopathic ulcerative colitis from $S$ typhimurium infection. In untreated ulcerative colitis the inflammatory cells are entirely neutrophil polymorphs with dumb-bell type abscesses with one part in the crypt of Lieberkühn and the other in lamina propria. In the author's experience the crypt abscess in $S$ typhimurium infection is never of dumb-bell shaped type. Most cells are neutrophil polymorphs, with eosinophil leucocytes, lymphocytes, plasma cells and mononuclear cells or macrophages. This appearance is indistinguishable from that seen in Sonne dysentery in Glasgow, but Flexner dysentery crypt abscesses may involve the lamina propria. The author has no experience with campylobacter infections but the description by Price $e t \mathrm{al}^{35}$ suggests that the changes resemble those of Flexner dysentery.

Superficial fibrinoid necrosis of the colon of patient 1 is unique but similar areas are evident in the colon of patient 6 and the appendix of patient 3 (Tables 4 and 5), as well as in a death from $S$ enteritidis infection (infra). The sequence of repair in other colons suggests that all experienced similar damage. The inference is that diffuse superficial fibrinoid necrosis is the earliest lesion in the colon, and is distinct from pseudomembranous colitis. ${ }^{36}$

The changes reported in this series of fatalities may not be representative of survivors, but some practical generalisations may be made. Although these patients had a single episode of infection, diarrhoea settled fairly rapidly after admission to hospital. The colon could be histologically normal by 12 days, (patient 4 , Tables 1 and 4 ), and certainly by 58 days (patient 9 ). Colonic inflammatory activity could persist for 19 days, (patient 6 , Tables 1 and 4 ) and subtle minor activity was still present at 29 days, (patient 8, Table 4). Thus, histological normality may take six weeks to return. This suggests that with a continuing diarrhoeal illness, the possibility of idiopathic ulcerative colitis should not be considered until after two months unless a biopsy within this interval shows classical histology in conjuction with several negative faecal and blood specimens. There need not be a community outbreak of food poisoning, as isolated cases of salmonella infection occur.

Histological appendicitis is part of the process. Repair is not as advanced in the appendix as it is in the colon of the same patient, and given the correct circumstances, appendicitis requiring operative treatment may evolve. ${ }^{37-39}$

The four patients reported by Story and Hanbury ${ }^{40}$ had different alimentary tract histology. It is possible that polyarteritis nodosa contributed more to the pathology of their case 1 than the authors believed. The gross and histological pathology could be very variable, but the colon appearances were not changed appreciably. Their patient 1 had a hospital acquired infection, a situation that has become more common ${ }^{41}$ and was probably the case in patient 1 of this report. Review of the literature disclosed that colonic ulceration (? ulcerative colitis) was reported in some studies, but none recorded acute diffuse ulcerating colitis. ${ }^{40}$ Appendicitis was identified as a complication. ${ }^{40}$ 
The author has gained experience from seven necropsies with $S$ aberdeen (1 case), $S$ brandenburg (1), $S$ enteritidis (1), $S$ heidelberg (2), $S$ panama (1) and $S$ virchow (1) infections and has examined colonic biopsies from patients surviving $S$ typhimurium infection. All had features similar to those reported here. Scanty gastric crypt abscesses occurred with $S$ enteritidis only. $S$ enteritidis infection failed to show enteritis (or enteropathy) ${ }^{3}$ whereas the two examples of $S$ heidelberg food poisoning showed extensive small bowel damage as well as colitis. ${ }^{3}$ Thus, the combined series of 16 patients suggests that not all salmonellae carry the enterotoxin $^{2122}$ or cytotoxin, ${ }^{24}$ and that yet other possible mechanisms have to be sought to explain the undoubted gastric and small intestinal clinical features. Superficial fibrinoid necrosis occurred in the colon with $S$ enteritidis as described above in patients 1,3 and 6 . The lack of gross features in the alimentary tract of all these patients is reemphasised, and some patients with infective diarrhoea will inevitably be categorised as having minimal change colitis. ${ }^{42}$

I wish to thank Professor T Anderson CBE (retd), Dr J H Lawson (retd) and Drs I W Pinkerton, W C Love, and D H Kennedy for permission to scrutinise the case records of the patients under their care, to Dr R J Fallon and staff of the Department of Laboratory Medicine for the micro-biological results without which this series of deaths would have been meaningless, and Mrs L Gilmour for preparing the manuscript. Thanks are also expressed to Mr E McWilliams FIMLS who prepared the illustrations and to the McMillan Fund of the University of Glasgow.

\section{References}

1 Sharp JCM. Gastro-intestinal infections in Scotland, 1970-81. Communicable Diseases Scotland, Weekly Report 1982: 16: (3): 7.

2 Boyd JF. Salmonella typhimurium, colitis and pancreatitis. Lancet 1969; 2: 901-2.

3 Boyd JF. Colonic involvement in salmonellosis. Lancet 1976; 1: 1415

4 Appelbaum PC, Scragg J, Schonland MM. Colonic involvement in salmonellosis. Lancet 1976; 2: 102.

5 Nichols GL, Nicholls MWN. Colonic involvement in salmonellosis. Lancet 1976; 2: 253.

6 Radšel-Medveščeck A, Žargi R, Ačko M, Zajc-Satler J. Colonic involvement in salmonellosis. Lancet 1977; 1: 601 .

7 Mandal BK, Mani V. Colonic involvement in salmonel- losis. Lancet 1976; 1: 887-8, and 2: 102.

8 Green PHR, Middleton WRJ. Salmonella typhimurium colitis. Aust NZ J Med 1976; 6: 345-7.

9 Day DW, Mandal BK, Morson BC. The rectal biopsy appearances in salmonella colitis. Histopathology 1978; 2: 117-31.

10 McGovern VJ, Slavutin LJ. Pathology of salmonella colitis. Am J Surg Pathol 1979; 3: 483-90.

11 Pennington CR, Bickerstaff KI, Lyall MH. Salmonella infection with colitis. $J$ Infect 1980; 2: 181-3.

12 El-Maraghi NRH, Mair NS. The histopathology of enteric infection with Yersinia pseudotuberculosis. Am J Clin Pathol 1979; 71: 631-9.

13 Dickinson RJ, Pickens S. Morbidity and mortality in salmonella food poisoning. Scott Med J 1978; 23: 23-26.

14 Hurst AF. The clinical importance of achlorhydria. $\mathrm{Br}$ Med J 1934; 2: 665-9.

15 Waddell WR, Kunz LJ. Association of salmonella enteritis with operation on the stomach. $N$ Engl J Med 1956; 255: 555-9.

16 Nordbring F. Contraction of salmonella gastroenteritis following previous operation on the stomach. Acta Med Scand 1962; 171: 783-90.

17 Gray JA, Trueman AM. Severe salmonella gastroenteritis associated with hypochlorhydria. Scott Med J 1971; 16: 255-8.

18 Giannella RA, Broitman SA, Zamchek N. Salmonella enteritis. I. Role of reduced gastric secretion in pathogenesis. Am J Dig Dis 1971; 16: 1000-6.

19 Giannella RA, Broitman SA, Zamchek N. Salmonella enteritis. II. Fulminant diarrhea in and effects on the small intestine. Am J Dig Dis 1971; 16: 1007-13.

20 Axon ATR, Poole D. Salmonellosis presenting with cholera-like diarrhoea. Lancet 1973; 1: 745-6.

21 Koupal LR, Deibel RH. Assay, characterization, and localization of an enterotoxin produced by Salmonella. Infect Immun 1975; 11: 14-22.

22 Jiwa SFH. Probing for enterotoxigenicity among the Salmonellae: an evaluation among biological assays. $J$ Clin Microbiol 1981; 14: 463-72.

23 Gangarosa EJ, Beisel WR, Benyajati C, Sprinz H, Piyaratn $\mathrm{P}$. The nature of the gastrointestinal lesion in Asiatic cholera and its relation to pathogenesis: a biopsy study. Am J Trop Med Hyg 1960; 9: 125-35.

24 Koo FCW, Peterson JW, Houston CW, Molina NC. Pathogenesis of experimental salmonellosis: inhibition of protein synthesis by cytotoxin. Infect Immun 1984; 43: $93-100$.

25 Giles G, Sangster G, Smith J. Epidemic gastroenteritis in infants in Aberdeen during 1947. Arch Dis Childh 1949; 24: 45-53.

26 Rosansky R, Berant M, Rosenmann E, Ben-Ari Y, Sterk VV. Enteropathogenic Escherichia coli infections in infants from 1957 to 1962 . J Pediatr 1964; 64: 521-7.

27 Kennedy DH, Walker GH, Fallon RJ, Boyd JF, Gross RJ, Rowe B. An outbreak of infantile gastroenteritis due to E. coli O 142. J Clin Pathol 1973; 26: 731-7.

28 Daniels JJH. Enteric infections with Pasteurella pseudotuberculosis. An acute abdominal syndrome. J Int Coll Surg 1962; 38: 397-411.

29 Curry JF. Acute terminal ileitis and Yersinia infection. Br Med J 1974; 1: 264-6. 
30 Moráin CO. Acute ileitis (Leading article) $\mathrm{Br}$ Med J 1981; 283: 1075-6.

31 Boyd JF. Acute ileitis. $\mathrm{Br}$ Med J 1981; 283: 1333.

32 Mills PR, Brown IL, Watkinson G. Idiopathic chronic ulcerative enteritis. $Q J$ Med 1980; NS 49: 133-49.

33 Dronfield MW, Fletcher J, Langman MJS. Coincident salmonella infections and ulcerative colitis: problems of recognition and management. $\mathrm{Br}$ Med J 1974; 1: 99-100.

34 Annotation. Toxic megacolon. Lancet 1979; 1: 480.

35 Price AB, Jewkes J, Sanderson PJ. Acute diarrhoea: campylobacter colitis and the role of rectal biopsy. $J$ Clin Pathol 1979; 32: 990-7.

36 Price AB, Davies DR. Pseudomembranous colitis. $J$ Clin Pathol 1977; 30: 1-12.

37 White MEE, Lord MD, Rogers KB. Bowel infection and acute appendicitis. Arch Dis Childh 1961; 36: 394-9.

38 Dadswell JV. Acute appendicitis and salmonella infections. Br Med J 1973; 1: 740.

39 Thompson RG, Harper IA. Acute appendicitis and salmonella infections. Br Med J 1973; 2: 300.

40 Story P, Hanbury WJ. Morphological changes in Salmonella typhimurium infections. J Pathol Bacteriol 1957; 73: 443-50.

41 Sharp JCM, Collier PW, Gilbert RJ. Food poisoning in hospitals in Scotland. J Hyg (Camb) 1979; 83: 231-6.

42 Elliott PR, Williams CB, Lennard-Jones JE, Dawson AM, Bartram CI, Thomas BM, Swarbrick ET, Morson BC. Colonoscopic diagnosis of minimal change colitis in patients with a normal sigmoidoscopy and normal air-contrast barium enema. Lancet 1982; 1: 650-1. 